\title{
双创背景下高校创新创业教育师资队伍建设
}

\section{Construction of Teachers in Innovation and Entrepreneurship Education in Colleges and Universities Under the Background of Mass Entrepreneurship and Innovation}

\author{
罗清 \\ Qing Luo \\ 宁德师范学院 中国·福建 宁德 352100 \\ Ningde Normal University, Ningde, Fujian, 352100, China
}

摘 要: 目前, 很多高校创新创业教育师资队伍建设还需要进一步完善, 普遍存在一些问题, 如教育理念有待更新、教师 数量不足、教师专业性需要提高等。为了有效改善这一现状, 政府部门出台创新创业教育相关政策作为支持, 并投入大量资金, 引导教师树立正确的创新创业教育理念，建立完善的考核激励制度，论文主要针对双创背景下高校创新创业教育师资队伍 建设进行了分析。

\begin{abstract}
At present, the construction of innovative entrepreneurship education teachers in many colleges and universities still needs to be further improved, and there are generally some problems, such as the renewal of educational ideas, the shortage of teachers, and the need to improve teachers' professionalism. In order to effectively improve this situation, government departments issued innovative entrepreneurship education related policies as support, and invested a lot of funds to guide teachers to establish a correct concept of innovative entrepreneurship education, establish a sound assessment and incentive system, this paper mainly analyzes the construction of innovative entrepreneurship education teachers in mass entrepreneurship and innovation.
\end{abstract}

关键词：双创；高校创新创业教育；师资队伍建设

Keywords: mass entrepreneurship and innovation; innovation and entrepreneurship education in colleges and universities; construction of teachers

基金项目：宁德师范学院 2019 年教改项目（JG2019031)

DOI : $10.36012 /$ sde.v2i11.2408

1 引言

创新创业教育的基本目标是提升大学生的专业技能、综 合素质，培养双创优秀人才，现已成为很多高校发展、建设 的关键内容。但是，中国创新创业教育仍处于初级发展阶段， 教育任务相对繁重，创新创业教育师资队伍建设面临着很大 挑战, 高校需要对其进行深入分析, 提出更多有针对性的对 策，建设高水平的双创师资队伍。基于此，文章阐述了双创 背景下高校师资队伍建设的重要性, 分析了双创背景下高校 创新创业教育师资队伍建设现状及对策。

\section{2 双创背景下高校师资队伍建设的重要性}

\section{1 满足社会经济发展需求}

在信息化时代，创新驱动发展战略是中国政府提出的
重要战略之一, 其主要是应对各项不确定因素带来的挑战, 为实现自我改革、创新、发展提出的重要战略 ${ }^{[1]}$ 。在现代社 会的发展中，社会各个行业都急需懂理论、实践、创新的复 合型优秀人才, 并对高校创新创业教育提出了更多新要求 高校需要强化创新创业教育师资队伍建设，适应现代社会经 济的发展。

\section{2 推动高校人才培养模式改革与发展}

高校教育教学的基本任务是立德树人，培养承担民族 复兴职责的新时代优秀人才。为了实现这一目标，高校需要 深化创新创业教育改革，根据社会发展需求，不断丰富创新 创业教育内容、方法 , 激发大学生的创新创业热情, 为实现 高校人才培养目标提供支持。目前，创新创业人才培养已成 为高校人才培养质量的重要衡量标准之一，高校需要强化师

【作者简介】罗清 (1988～), 女, 福建福安人, 讲师, 从事创业及企业管理研究。 
资队伍建设, 全面落实创新创业教育改革工作, 以满足现代 高校人才培养改革、发展的需求。

\section{3 双创背景下高校创新创业教育师资队伍建 设现状}

\section{1 师资队伍综合实力有待提高}

据统计，在创新创业能力培养过程中， $20 \%$ 以上的毕 业生认为自身的创新创业能力培养还无法满足实际发展需 求。现阶段，高校创新创业教育师资队伍建设面临着两方面 内容: 第一, 师资数量不足。现阶段, 很多高校的创新创业 教育师资最多在十几位左右, 这些教师普遍是校内兼职教 师; 第二, 青年教师的创新创业意识相对薄弱, 中青年教师 在创新创业教学指导活动中所占比例比较大, 但这些教师的 创新创业实践经验、基础理论知识严重不足，受创新创业发 展需求、创新创业教学实力之间的影响，制约着高校创新创 业人才的培养。

\section{2 创新创业教师实际投入不足}

在现代化社会的发展中，国家政策趋势、就业形势发展、 大学生创新创业需求在不断改变, 高校在不断改革自身的创 新创业教育发展方案, 并对高校教师提出了更多新要求。现 阶段, 高校教师逐渐认识到创新创业教育发展对自身发展带 来的机遇, 促使大学生积极参与创新创业教育活动中。但是, 高校内部发展制度、激励制度还需要进一步完善, 受教学、 科研压力的影响, 很多创新创业教育教师面临很大压力, 导 致教师很少参与创新创业教育活动, 普遍将创新创业教育工 作作为自身工作的一部分, 只能够勉强应付, 很难用尽全力 投入实际工作中。

\section{4 双创背景下高校创新创业教育师资队伍建 设策略}

\section{1 营造全员参与创新创业教育改革的氛围}

教师是教育教学改革的推动者、实施者，但创新创业 教育师资队伍力量相对薄弱, 为了有效改善这一现状, 高校 应集中全校力量，建设高、精、专的创新创业师资队伍，建 设具备地方特色、自身要求的创新创业教育师资体系, 针对 理论教学、实践教学等内容进行优化, 为创新创业教育发展 提供基础保障。另外, 高校需要引进更多社会力量, 如创新
创业典范，建设创新创业兼职教师队伍，提高创新创业教育 的整体效果，还需要引导、鼓励各个专业教师将创新创业理 念、知识渗透到专业课程教学中，营造积极参与创新创业教 育改革的局面。

\section{2 鼓励参与骨干教师培训}

现阶段, 高校需要积极参与创新创业骨干教师培养活 动中，加强和当地政府部门之间的联系，共同组织开展创新 创业教育骨干教师培训活动，根据高校实际情况，安排创新 创业师资队伍中的教师积极参与培训活动，提高创新创业指 导教师的专业技能、综合素质。同时，高校需要根据实际情 况，合理调整培训活动的开设周期，引进更多现代化创新创 业教育活动方式，还可以邀请知名教育家、创业者、企业家， 积极开设 “名师讲坛”，重点讲解先进的高校创新创业教育 形式、理论基础、实践问题，分析创新创业教育课程体系、 组织活动，有效覆盖创新创业教育指导问题，并采取相应措 施进行优化，提高高校创新创业教育水平。

\section{3 优化教师团队资质结构}

目前，高校需要根据自身的实际情况，选择优秀的教师、 教授，建设全面、多层次的创新创业教育师资队伍。高校还 需要及时调整薪资待遇结构，稳定创新创业教育师资队伍的 人才资源，鼓励优秀骨干教师积极参与队伍建设中，为学生 提供更多学习、提升的机会，建设轻松、愉悦的工作氛围， 使其加深对运营、管理、发展的理解，不断丰富教师的创新 创业教育经验。

\section{5 结语}

综上所述，在创新创业教育驱动、发展的大背景下， 高校创新创业教育改革势在必行。在双创背景下，高校需 要认识到创新创业教育的重要性, 根据时代发展需求，积 极开展创新创业教育活动，建立完善的创新创业课程平台， 形成全员参与创新创业教育改革的新局面，培养更多创新型 优秀人才。

\section{参考文献}

[1] 洪柳华. “双创” 升级背景下高校创新创业教育师资队伍建 设研究 [J]. 辽宁经济职业技术学院·辽宁经济管理干部学院学 报, 2019(6):94-96. 